\title{
TOURIST DESTINATION MANAGEMENT
}

\author{
Karmen Andrea MEZEI \\ Faculty of Economics, University of Oradea, Romania
}

\begin{abstract}
Tourism development has environmental and social consequences upon local and global communities. The impact of tourism must be kept within certain limits which are set up by sustainable tourism. Meanwhile the viability of the investment must be assured. Tourism development matrix is the tourist destination. Destination management must ensure the balance between economic, social, cultural, and environmental activities. Competitive destination management organization means a harmonious combination between planning, lobby, coordination and marketing (promotion). The recommendation of an integrated meta plan for Romanian balneal spa could be the choice for a successful tourism development.
\end{abstract}

Key words: sustainable tourism, destination management, environment, local communities, meta plan

JEL classification: Q01, Q56

\section{INTRODUCTION}

Tourism is a sector of economy that affects the global development of a country. Moreover sustainable tourism means using the present resources without negatively affecting the resources of the next generation.

Numerous researchers within tourist industry have tried to define the nature of tourist destination. The aim of this paper is to try to clarify the concept of tourist destination management. We are examining to what extent the theoretical approach applied to tourist destination management agrees with the existing conditions of Romanian balneal treatment spa in Bihor County. After 1989 we could notice a lack of coordination in the tourist activity and tourist organizations due to profound political, economical, and social changes which characterizes all former communist countries.

It is recommended that we explain the concept of tourist destination, organizing and coordinating tourist activities within the same area, and how sustainable development becomes the choice for a viable outcome. For this purpose it will overlap theoretical frame over the existing management system of a balneal treatment spa which becomes tourist destination after suiting certain requirements set by sustainable development.

Tourist destination is defined as 'a package of tourism facilities and services which like any other consumer product is composed of a number of multidimensional attributes' (Hu et al, 2003; Presenza, 2005). The destinations are combinations of tourist products (Buhalis, 2000) offering an integrated experience to consumers.

A more accurate delimitation of the concept would be from the perspective of demand. Others (Leipner, 1995; Martini, 2001; Pechlaner, Weiermaier, 2000) advocate a substantial identification of a destination as a set of products, services, natural and artificial attractions able to draw tourists to a specific place and thereby affirm that geographical position does not coincide with destination. A destination coincides with the notion of a locality seen as a set of products/experiences, influenced in a critical way by the companies' attitudes and their willingness to cooperate (De Araujo, Bramwell, 2000). Therefore, one must recognize that the destination is an entity whose component parts are interdependent; a change in one has implications for all of the others.

Tourist destination management is the science of organizing and conducting tourist destinations, efficiently using human, financial and material resources. Tourist destination management organizations should have tasks according with the objective of the organization. The question that rises is, whether these destination management organizations can emerge from existing tourist enterprises or tourist development entities in Romania.

The management of tourist destination is made up by the sum of strategical, organizational, and operational decisions taken to define, promote, and sale the tourist destination product, and by the decisions to influence and drive the flow of tourists to/from a region, respecting the economical requests of the tourist activity participants in that area.

According to Franch and Martini it is possible to define destination management as the strategic, organizational and operative decisions taken to manage the process of definition, promotion and commercialization of the tourism product and to generate manageable flows of incoming tourists that are balanced, sustainable and sufficient to meet the economic needs of the local actors involved in the destination.

Understanding the role of tourist destination in the development of certain regions is strongly related to the concept of sustainable development. Sustainable tourism/development represents the satisfying the consumers' demand of tourist products considering the necessities of future generations of consumers without negatively affecting the environment and tourist 
resources implicitly (World Commission on Environment and Development, 2008).

\section{TOURISM SEEN AS SUSTAINABLE DEVELOPMENT}

Tourism seen from the perspective of sustainable development requires the equilibrium of three aspects: economy, environment, and the sociocultural aspect (Wittmer, Riklin, 2007). From economic point of view tourism must use infrastructure and follow up costs which may appear in this process, optimize the marketing effect (the image of tourist destination), create and secure information related to tourism activities and integrate in the networks of industries. Environmental protection must deal with the negative impact from building infrastructure, generated traffic, noise pollution, creation of natural resources management system, and strictly following the rules / regulations in this field. Social and cultural activities must amplify regional identity seen as a cultural identity, pursue strong implication of locals, and promote a positive view of the community. Social and cultural activities are related to their location seen as a tourist destination and opportunity for future generations to be involved in the effective management of tourist destination from which they arise.

Organizing and leading a destination, in other words the management must respect the requirements of a sustainable tourism which has a series of benefits. These benefits are economical, social, and ecological. Economical benefits could be: positive trade balance, improvement of the trade activity in a region due to the presence of tourist destination, low unemployment rate, multiplier effects (Ban, 2006), added value at regional level, and added value at the level of income from tourist activities. Social benefits could be: rising life quality or welfare, numerous employment opportunities, cultural exchange between locals and tourists, protection / conservation of heritage, and customs / tradition. In order that tourism of destination should be qualified as sustainable it must have ecological and environmental protection benefits within managerial decisions. These management decisions are the protection / preservation of natural environment and the education of tourist mass related to environmental protection.

\section{DIRECTIONS FOR A COMPETITIVE MANAGEMENT AT TOURIST DESTINATION LEVEL}

Organizing and leading a tourist destination involves managers' actions for four directions: planning, coordination, lobby, and marketing, these actions are considered tasks of a tourist destination manager and a service manager as well.

Planning means complying with the mission of a destination and the mission of all companies involved in this system. Thus, the tourist product is the final result of the efforts made by the service manager (Lovelock, 1983). While planning means a close study of markets, of the necessities that are needed to satisfy the tourist demand, and the coordination of service as a highly complex process which involves respecting the rule of the four P: planning (politics), product, process, and price. The questions that rise are: Who are buying our products? What are we selling? How to sell? What is the best price to sell?

Lobby means the implication of political variables in the promotion of a tourist destination which is a vivid process. This political side of destination management becomes decisive, especially regarding regulation referring to the development of tourist entities, which sets the volume of financial resources directed to certain regions with the purpose of improvement and growth, which means sustainable tourist activity in that region. The gain of high profits obtained from tourist activity implies a strategic governmental thinking and the presence of a national, regional or associative authority. The core objective becomes promoting the tourist destination.

Service coordination might be interpreted as supply dependent. Public transport can be a part of the tourist product and a public service in the same time and its main feature is, without doubt, rapidity. This characteristic of public services depends on the regional infrastructure. The existence and development of a viable infrastructure depends upon decisions taken by local councils regarding regulation, and directing of resources to these destinations. The image of tourist destination is related to these macrostructures. Tourist product can have positive and negative external impacts. An example is overstressing urban transport which can lead to dissatisfaction among inhabitants. Local political parties delegated to implement the development plan of a region are unlikely to win elections in that region if they failed to meet certain psychological limits set up by inhabitants of that area.

Marketing of a tourist product implies promoting a tourist product. A tourist product is a bundle of goods and services offered in a certain environment at a given price with a certain delivery schedule. Tourist product comprises an array of abstract ideas.

Promotion seen as a marketing method becomes decisive in a very competitive tourist environment like South Eastern Europe (traditional 
thermal spas along the border of Hungary and Romania, and the new spas developed recently). This aggressive promotion must use all available channels: television (advertising spots aiming to promote a country), training of personnel for promoting destination, as part of the tourist product, using newspapers, brochures, magazines, flyers and Internet promotion. Internet promotion is the ultimately high way for providing information to service consumers.

The competitive nature of a tourist destination brings up the necessity of a centralized management. This centralized management can be achieved only respecting the recommendations of sustainable tourism. Failing to obey the requirements of a sustainable tourism will turn its advantages into disadvantages that would lead to stagnating or even falling indicators of profitability in the tourist area!

\section{DESTINATION ORGANIZATION}

MANAGEMENT

Due to the complexity of the tourist destination management it is necessary to create an organization. This organization may be responsible for directing the tourist activity in a certain region taking into consideration the variety of service enterprises which set up the tourist product. All parties taking part in the tourist organization must be involved in: planning, marketing, coordination, and lobby activities.

Concerning planning it is recommended that the organizations, companies, government, tourist enterprises located in a certain region, and different types of national/regional authorities should create a development concept or a thorough plan for the tourist destination, a development strategy for the tourist destination. Any strategy (Botezat, 2003) must have: clearly defined objectives (these objectives emphasize the development direction of a tourist destination), time schedule associated with objectives, and allocation of resources for the purpose of reaching stated objectives.

Development of a strategy includes also "bi" dimensioning the supply or "designing" the supply (setting up an information centre or an information office). It is easier to sell a product if the consumers are aware of its features. The organizations of destination management should smooth the process of promotion and commercialization. Promotion means shaping tourist offer, careful design of the tourist product that will provide benefits to both parties.

Careful design of the tourist products ready to be sold, maintenance of the quality development system/quality assurance system that can provide accurate/up to date information regarding opinions/emotions of tourist product consumers, and organizing events, symposiums, conferences that will imply a large participation of tourism consumers represent a number of dimensions of the touristic offer. Lobby means spreading information among tourist industry participants (Leidner, 2004), among locals, encouraging responsible behaviour in tourism, political implication for viable projects regarding competitiveness of destination (Dwyer, Chulwon, 2003), but not implying political factors in the first steps of implementation of a development strategy for a destination.

The marketing function of a tourist organization comprises development of a marketing strategy; assurance of the appropriate level of marketing research, including qualitative and quantitative evaluations of tourist activities; assurance of brand management (positioning, care for the brand, cooperation strategies) (Wittmer, Riklin, 2007; Pike, 2006).

A destination brand is 'a name, symbol, logo, word mark or other graphic that both identifies and differentiates the destination'. Furthermore destination brand conveys the promise of a memorable travel experience that is uniquely associated with the destination. Destination brand also serves to consolidate and reinforce the recollection of pleasurable memories of the destination experience (Baker, 2007).

\section{CASE STUDY: INTEGRATED DEVELOPMENT META PLAN FOR BĂILE FELIX SPA}

As o modality of development it is recommend setting up an Integrated Meta Plan. A meta plan is a complex project that supposes careful research regarding the tourist potential of a designated region, the development opportunities and the competition, the advantages and disadvantages, the promotion, and also the tariffs applied to goods and services. All actions, undertaken as part of the project, have to be done in order to meet the standards of a tourist destination. The Integrated Meta Plan is seen as a global sum of efforts of all “"stakeholders” (Ionescu et al, 2003) involved in tourist activities in a certain area strictly following the tendencies on the international market, on potential markets, and the tourist potential of the mentioned region.

First there are considered the tendencies of demand on international markets, in balneal tourism and on potential markets, defined by certain characteristics as number of potential visitors/tourists. Romanian tourist market faces changing demand. This situation requires restructuring the concept of balneal tourism using a modern one applied in other parts of Europe. Restructuring the balneal tourism supposes a clear definition of a new form of tourism: health tourism (Mihai, 2007). Health tourism is a recreational, therapeutic system. There are interactions taking place within this system between variables like: curing, preserving health education, training, general atmosphere, sport, relaxations, quietness, and change of life style. All these could determine elimination of 
stress (second most important health problem in U.E.) and tiredness due to overstressing situations at work, and day by day activity.

Potential tourism activity at Baile Felix Spa is determined by: thermal water used for recreation, balneal treatment, relaxation, and wellness (prevention of appearance of a $21^{\text {st }}$ century disease). The water lily (Nymphea lotus thermalis), dated far back to the Tertiary period (Şoldea, 2003), unique on our continent, is considered attraction number one. The proximity of the forest and health walking tours, trips to the Betfia cave and to the famous natural thermal lake at 1 Mai resort - the biggest thermal natural reservation preserved in the country, are among the main attractions in the area. Leisure activities are: ski, sleigh, snowboarding at Hidişel, a location close to Felix Spa; there are mentioned out door activities such as: jogging, biking, paintball, horse riding at "Prezident", a balneal complex situated in a wonderful natural environment within Felix Spa.

There is a plan to build a recreational centre. The name of the project is 'Aqua Parc' administrated by Sânmartin, a rural community located in the vicinity of Felix Spa. This centre will consist of: pools for kids and adults, water slides, water fall type pools, water bars/restaurants, an artificial lake good even for boat rides, a channel type pool with tide, an open air theatre, parking lot, sports centre, and green spaces. The centre will also accommodate: cinemas, a shopping center, sauna facilities, hospitals, restaurants, bars, pubs, open air facilities, and a hotel able to accommodate $250-500$ people.

Tourist activities must be sustained by a rapid and safe transportation system. Project 'Aqua Parc' is designed with easy access ways; improving road systems already in use (the estimated time to finalize the projects is 2 years); the idea of running a public transportation bus line that will connect every part of the metropolitan city of Oradea (the main town in Bihor County); the private owned train line between Oradea and town of Beiuş, will facilitate access in this destination area for more tourists. The train line will be available for public use soon.

Balneal and health tourism have a target market of a specific age group: people over 45 years of age that need balneal treatment and wellness services, residents of Romania. This target market has certain characteristics: familiarity with places and hotel staff, these people are attracted by high level services offered at special prices, national plans for retirement programs, attractive low season tourist packages, and possibility of meeting people of same age. Another target market for this project are people over 45 years of age that need balneal treatment and wellness, residents of Germany, Austria, Israel, attracted by: natural cure factors, a high level of services offered at lower prices as compared to back-home prices (due to agreements and contracts between S.C. Turism Felix and tourism agencies from abroad), of tourist packages provided, Romanian tradition, folklore, cultural heritage, food specialties, and handcrafts. Families with kids, residents and foreign tourists are attracted by: supplemental services for kids at low prices, short vacations, and natural cure factors. The offer of conference rooms fully equipped, good organization and convenient prices for larger groups, 'all inclusive' packages (accommodation, meals, conference, and wellness), draw the attention of business tourists, companies, and organizations. Leisure activities are easy to reach within the accommodation unit area: thermal pools, massage, sauna, and wellness treatment. Felix Spa entices young couples with possibilities of wedding celebrations, possibilities of organizing large events in this sector, vivid catering development services, and honey moon packages.

Leisure opportunities in the area are: architectural, cultural and religious: city tours of Oradea; concerts at philharmonics in Oradea; Bears Cave from Chişcău, unique in our country; Mountain resort Stâna de Vale; mountain side village Şuncuiuş with famous Romanian dishes at 'Dracula Restaurant' and picturesque vicinities; Cefa, Inand and Tămaşda lakes for amateurs fishers, and facilities for preparation of fresh fish dishes on the spot; Paleu and Săldăbagiu locations belonging to the metropolitan area of the main city Oradea offering wonderful possibilities of weekend breaks for walking, sunbathing, camping, fishing, and serving traditional meals at local food/beverage facilities; Betfia Cave and the biggest natural reservation of this kind in the country - 1 Mai- where the water lilies grow freely for millions of years; city tours of Cluj Napoca, Debrecen, Timişoara; hunting trips, organized in the north-east part of the county, close to the town of Valea lui Mihai, preferred species being bears.

The SWOT analysis refers to the following:

Strengths: geothermal waters for health and leisure activities; variety of accommodation facilities including new facilities; proximity of the forest and the fresh air; geographical position; valuable medical treatment procedures (Rădulescu, 2006); aqua park project in implementation (ready by 2011); implementation of waste management strategy.

Weaknesses: old accommodation units waiting for viable investment strategies; lack of green areas; insufficient sport grounds; limited leisure activities (it is estimated that the aqua park will be finalized only in 2 years); limited shopping possibilities; poor tourism infrastructure, lack of hallmarks, information centres; overbuilding of sites without taking into consideration space availability for leisure and shopping and without respecting recommended quota of $42 \%$ - between constructed area and total land available for public constructions; dependency of water flows of meteorological and climate factors (Negoescu, 1998); heavy thermal drillings; lack of symbols and specificity of the area; too many unskilled people employed; unsatisfactory grades while evaluating personnel-low productivity; low efficiency of the marketing activity (Prideaux, Cooper, 2002). 
There is room for new development ideas for Băile Felix touristic resort considering the macrosystems of transport, the old accommodation and balneal treatment units, the requirement to adjust our environmental regulations to those of the E.U., the possibility of getting financial help from E.U. partnership projects which involve the association of two or more areas in order to develop their touristic potential by reducing their research costs, the lack of advertising. Ideas could be: organizing and taking part in fairs and exhibitions related to tourism; selecting properly trained staff, of different ages and up to 40; improving the local infrastructure (especially by finishing the motorway/highway with exits relatively close to Băile Felix); carrying out the project involving a bus line that connects all the villages surrounding Oradea, thus a higher accessibility of the resort for the nearby communities; privatizing the railway line between Oradea and Beius and starting to use it within a short time; the "Aqua Parc" project which is in the stage when work has just begun; accessing to E.U and governmental funds; the possibility of developing partnerships with other communities within the E.U.; the existence of legal regulations regarding the quality of surface and underground waters; the existence of a monitoring system for the air quality; the existence of a plan to reduce emissions of large burning plants (I.M.A.), that is included in the National Plan to reduce Emissions for I.M.A.; the inexistence of major sources of pollution in the area; closing inadequate dumps from the countryside starting from $16^{\text {th }}$ July 2009, cleaning the area and introducing them into the natural circuit.

In order that a destination should become a market leader, it must be situated in a more favourable site than its competitors. Becoming a market leader means a touristic offer addressed to consumers with certain income and a range of needs which permanently changes. The main constituent of the touristic offer is thermal water, a perishable natural resource which has to be properly managed, and the balneal treatment which uses this resource is performed with the aid of a modern device. In this respect the threats of Băile Felix resort are: resorts from Hungary situated near the border, less than 80 $\mathrm{km}$ far, which compete successfully with the offer of the Romanian resorts, for example Hajdúszoboszló, which is the largest resort (Mitroi, 2008) from central and eastern Europe; the technical development of the medical apparatus used in the treatments leads to the quick moral wear of the equipment used in the present; the rapid change of the tourists' preferences; nowadays the tourists want mobility, relaxation and places for entertainment - the new tendency (Batchelor, 2007) is the circuit tourism; the wrong impression of the foreigners who 'don't know us' and think that Romania is a country which lacks civilized citizens; the instability of the governmental politics referring to tourism (Botezatu, 2003); the radon infected thermo mineral waters are "living waters" (Negoescu, 1998).

In order to create tourist product "Băile Felix" it is advised to include: balneal treatment, health treatment, tourism generated by conferences and events, sports tourism, transit tourism (referring to those who just "stop by" in the resort), relaxation tourism, and traditional amenities. It is suggested improving existing infrastructure respecting certain architectural lines. Cultural heritage must be promoted and offered to tourists not only as souvenirs, but as proofs of Romanian heritage on these sites. Regional values like Romanian traditional food dishes and handicrafts (like pottery) are values that represents Crişurilor region in the western part of the country.

Regarding price strategy it is recommended: special prices for the low season, special prices for packages including accommodation, meals and treatment, special prices for groups, special prices for tourism employees, special prices for children, special prices for organizers, group leaders, special offers and gifts for devoted guests.

Concerning promotion it is recommended: creation of a regular and electronic information centre; placing in tourist indicators, hallmarks and maps within tourist areas; movies, publicity spots on tourism websites; promotional CD-s; information offices within accommodation units area; familiarization tours for Romanian and foreign managers of tourist agencies; guided tours for journalists; creation of a festival on a certain subject like thermal water; wide participation at tourism trades and fares; organizing of fares and exhibitions.

\section{CONCLUSION}

In order to enable Romanian spas to become tourist destinations it is suggested a thorough analysis of the factors that influence the touristic demand and offer at a local level. The tendencies of the international market must not be ignored. The management of a touristic destination must be done with the help of an integrated development metaplan. There is an efficient coordination of the tourist destination only when it ensures a balance on the level of economy, environment and socio-culture. This balance is a fundamental condition for a sustainable tourism, which, thus, becomes the first action scheme for an efficient coordination of the tourist destination. The success of the touristic activity should be the result of collective effort from all the participants that contribute to the making of the touristic product, and the destination management organizations should do what every service manager is doing: planning, coordinating, lobby and marketing. There are huge lacks in the planning of tourist activity in Băile Felix, considering the size of the recreation centre project "Aqua Parc". The influence of governmental representatives is not enough to change the attitude of 
the local authorities. Promotion involves important financial resources, but it cannot be done until the obsolete infrastructure has been renewed, and that supposes that money is granted through governmental or E.U. action plans. Coordination means involving experienced staff in the field and reinforces the efforts of national and international specialists.

\section{BIBLIOGRAPHY}

1. De Araujo, L.M., Bramwell, B. (2000) Partnership and regional tourism in Brazil, Annals of Tourism Research, 29(4), 1138-1164, pp.371 http://www.sagepublications.com.

2. Baker, B. (2007) Experts insights on branding places- Total destination management, http://www.destinationbranding.com/articles/Expert_Insights.pdf.

3. Ban, O. (2007) Tehnici promotionale şi specificul lor în turism (Promotional techniques and their peculiarities in tourism), Editura Economică.

4. Batchelor, R. (2007) Turismul balnear din România, pe cale de dispariție (Balneal tourism in Romania is $\begin{array}{llll}\text { disappearing), } & \text { Bloombiz, } & 02 & \text { Aprilie }\end{array}$ http://www.bloombiz.ro/lifestyle1/turismulbalneardinromaniapecalededisparitie.

5. Bieger, T. (1998) Re-engineering destination marketing organisations: The case of Switzerland, Tourism Review, 53(3), pp.7.

6. Botezat, E. (2003) Strategii manageriale în turism (Management strategies in tourism), Editura Economică, Bucureşti.

7. Botezatu, G. (2007) Turismul balnear ar trebui să se trateze cu banii statului (Balneal tourism should be treated with governmental money), (Ediție din arhivă) Anul 12, nr. 4934, pp.2, http://www.curierulnational.ro/Economie/2007-06-18/Turismul+balnear+trebuie+sa+se + trateze +cu +banii +statului.

8. Buhalis, D. (2000) Marketing the competitive destination of the future. Tourism Management, 21(1), pp.97-116, http://www.sagepublications.com.

9. Dore, L., Crouch, G.,I. (2003) Promoting destinations: An exploratory study of publicity programmes used by national tourism organizations, Journal of Vacation Marketing, Vol. 9 No. 2, Australia, pp.2, 143, http://www.sagepublications.com

10. Dwyer, L., Chulwon, K. (2003) Destination Competitiveness: Determinants and Indicators, Current Issues in Tourism, Vol.6, No.5, pp.45, http://www.sagepublications.com.

11. Franch, M., Martini, U. (2002) Destinations and Destination Management in the Alps: A Proposal for a Classification Scheme in the light of some ongoing experiences. Paper presented at meeting 'Territoirs et marches 2eme colloque de recherché en Tourisme de L’Association francaise des IUP Turisme, Hotellerie et Loisirs, Universite de Savoie, Site de Chamberie (F).

12. Hu, Y., Ritchie, J.R.B. (1993) Measuring destination attractiveness: A contextual Approach, Journal of Travel Research, 32(3), pp.26, http://www.sagepublications.com.

13. Ionescu, G., Cazan, E., Negruşa, A. (2001) Management organizațional (Management of the organization), Editura Tribuna Economică, Bucureşti.

14. Lovelock, C.H. (1983) Classifying services to gain strategic marketing insights, Journal of Marketing, vol.47, pp.12.

15. Leidner, L. (2004) The European tourism industry, A multisector with dynamic markets, Structures, developments and importance for Europe's economy, European Commision, Chapter Summary and conclusions, http://ec.europa.eu/enterprise/services/tourism/doc/studies/european_tourism_industry_2004/european_tourism_ industry_2004_en.pdf.

16. Leiper, $\quad$ N. (1995) Tourism management, Melbourne: $\quad$ RMIT, http://cmstest.jcu.edu.au/business_prod/idc/groups/public/documents/journal_article/jcudev_012834.pdf.

17. Martini, U. (2001) Da luoghi a destinazioni turistiche. Ipotesi di applicazione del destination management al turismo alpino in M.Franch, Destination mnagement: alla ricerca di una soluzione possibile, Torino, Italy: Gianppichelli

http://www.francoangeli.it/Riviste/Scheda_Riviste.asp?IDArticolo=18425\&Tipo=Articolo\%20PDF.

18. Mihai, Ş. (2007) Perspectivele dezvoltării turismului de sănătate în România, SPA Tourism perspectives in Romania, Colegiul Economic A.D. Xenopol http://www.spiruharet.ro/ei/SectiuneaB/Mihai\%20Stefania.pdf.

19. Mitroi, M.D. (2008) Turismul balnear în Ungaria (Balneal Tourism in Hungary) http://www.agenda.ro/news/news/5637/turism-balnear-in-ungaria.html.

20. Negoescu, I. (1998) Băile termale Felix în pragul mileniului III (Thermal Spa Felix close to the IIIrd millenium), Asociația prorecuperare din termalism-Felix.

21. Pearce, D. (1992) Tourist organizations, Ed. Longman Group UK Ltd., Harlow, Essex, England. 


\section{[Nr. 8]}

22. Pike, S. (2006) Destination decision sets: A longitudinal comparison of stated destination preferences and actua, Journal of Vacation Marketing, Vol. 12 No. 4, Australia, pp.319-328 http://www.sagepublications.com.

23. Pechlaner, H., Weiermaier, K. (2000) Destination management: Fondamenti di marketing e gestione delle destinazione turistiche, Touring Ed., Milano, Italy.

24. Presenza, A., Sheehan, L., Brent Ritchie, J.R. (2005) Towards a model of the roles and activities of destination management organizations, Canada, pp.319-328,

http://hotel.unlv.edu/pdf/The\%20Role\%20of\%20the\%20DMO\%20Final \%20launching\%2010-22-05.pdf.

\%2version \%20for

25. Prideaux, B., Cooper, C. (2002) Marketing and destination growth: A symbiotic relationship or simple coincidence?, Journal of Vacation Marketing, Vol. 9 No. 1, Australia, pp. 2, 35-51, http://www.sagepublications.com.

26. Rădulescu, N. (2006) Turismul balnear trebuie să rezolve patru puncte slabe ca să fie competitive (Balneal tourism must solve four weaknesses to become competitive), Mediafax, http://www.zf.ro/articol_102316/turismulbalnear trebuiesarezolvepatrupuncteslabecasafiecompetitiv.html.

27. Ritchie, J.R.B., Crouch, G.I. (2003) The competitive destination: A sustainable tourism perspective, Ed. CABI Publishing, Wallingford, UK.

28. Şoldea, V. (2003) Peța şi nufărul termal (Peța waters and the water lily), Editura Universității din Oradea.

29. Toffler, A. (1980) The Third Wave.

30. Wittmer, A., Riklin, T. (2007) Advanced Education in Destination Management and Destination Marketing, Institute for Public Services and Tourism, University of St. Gallen, Switzerland.

31. *** Turismul balnear din România, pe cale de dispariție (Balneal tourism in Romania is dissapearing), Bloombiz, 02 Aprilie 2007, http://www.bloombiz.ro/lifestyle1/turismul-balnear-din-romania-pe-cale-dedisparitie.

32.*** Comisia Mondială pentru Mediu şi Dezvoltare(WCED),
http://ro.wikipedia.org/wiki/Dezvoltarea_durabil\%C4\%83. 